Article

\title{
The Sustainable Development Goals (SDGs) as a Basis for Innovation Skills for Engineers in the Industry 4.0 Context
}

\author{
Felipe Muñoz-La Rivera ${ }^{1,2,3, * \mathbb{C}}$, Pamela Hermosilla ${ }^{4}$, Jean Delgadillo ${ }^{1}$ and Dayan Echeverría ${ }^{5}$ \\ 1 School of Civil Engineering, Pontificia Universidad Católica de Valparaíso, Av. Brasil 2147, \\ Valparaíso 2340000, Chile; jean.delgadillo@pucv.cl \\ 2 School of Civil Engineering, Universitat Politècnica de Catalunya, 08034 Barcelona, Spain \\ 3 International Center for Numerical Methods in Engineering (CIMNE), 08034 Barcelona, Spain \\ 4 School of Computer Engineering, Pontificia Universidad Católica de Valparaíso, Av. Brasil 2241, \\ Valparaíso 2340000, Chile; pamela.hermosilla@pucv.cl \\ 5 Valparaíso Makerspace, Pontificia Universidad Católica de Valparaíso, Av. Brasil 2147, \\ Valparaíso 2340000, Chile; dayan.echeverria@pucv.cl \\ * Correspondence: felipe.munoz@pucv.cl
}

Received: 12 July 2020; Accepted: 7 August 2020; Published: 16 August 2020

\begin{abstract}
Teaching methods for calculation and project development, focusing on theoretical principles and the reproduction of validated procedures, has been the traditional focus of engineering education. Innovation has been present in universities, mainly in the creation of processes and technologies for the development of products, services, or companies, based on entrepreneurship. Training in innovation has been limited to interested students, and not encouraged for all students, despite how relevant it is for current and future global development. According to the literature research and the opinion of the experts, this research identifies the characteristics of innovation that engineering students should acquire, in response to the challenges of engineering in the 21st century, considering as a basis the Sustainable Development Goals (SDGs), in the context of the increasingly demanding requirements of industry 4.0. The identification of the relevant aspects in innovation were categorized according to the expertise and academic performance of the authors. In addition to this, the investigation of the representative elements of Industry 4.0, and the incorporation of Sustainable Development Goals, establish the basis of this study to guide the development of innovation skills in the process of engineering student education. Furthermore, in order to integrate innovation skills, elements of Industry 4.0 and aspects of Sustainable Development Goals, the concept of competence is introduced, with a conceptual structure that considers knowledge, attitude and performance context, thus this research provides a conceptual framework for those interested in constructing innovation skills in engineering, oriented towards the development of an innovation culture and mentality, as part of the expected professional performance.
\end{abstract}

Keywords: Sustainable Development Goals (SDGs); innovation skills; engineering education; Industry 4.0

\section{Introduction}

Industry 4.0 represents a new paradigm of digitalization and automation of manufacturing processes, but it not only aims at optimizing production itself, but also considers the organization as a whole, mobilizing in a certain way the focus towards a digital business model, which integrates IT infrastructure and service providers, manufacturing aspects and the importance of data, includes collection from different sources, applying analysis techniques in order to generate information that promotes collaborative spaces 
to improve the value chain. It proposes the implementation of intelligent working environments, widely interconnected, automated, robotized and systematized at a high level [1]. This transformation from traditional industry will demand new skills and competencies from workers [2]. In the area of engineering, professionals with extensive digital skills, agile learning, teamwork, problem solving, effective communication and innovation will be required. These individuals will be required to know how to respond to new production plant operations and successfully integrate digital and automatic work dynamics [2].

In the context of the 21st century, and in response to the existence of industries and the economy, nations have established a series of agreements to align global development policies in a common framework to safeguard global sustainability [3]. The Sustainable Development Goals (SDGs) correspond to 17 goals within a universal agreement that seek to address the empirical and scientific evidence that the world needs a more sustainable approach to its development actions [4]. In this context, it highlights the importance of innovation in successfully responding to the professional challenges of Industry 4.0, in line with the commitments of the sustainable development goals. Dynamic and innovative professionals will be key to the integration of production systems, the efficiency of human interaction-automatic systems, and the solutions to new problems that will arise along with these production systems [3].

These innovation characteristics incorporated in the context of industry 4.0 and SDGs must consider soft skills and technological competencies, from the perspective of the management and integration of people to the actual knowledge and mastery of digital tools [5]. The global engineering industry has established different characteristics for the innovative engineer: adaptable, constantly searching for solutions, able to experiment and integrate, possessing extensive knowledge and leadership qualities, curious and communicative, responsible, persistent, passionate, collaborative, creative, visionary, challenging, and with strong business intelligence and user-focused [6,7]. Although there is evidence of the demands from the industry for its professional engineers in the face of these new challenges (digital competencies, sustainability education, skills for Industry 4.0) [3], the vision from the training environments, regarding the formation of these competences in university engineering students, has not been widely studied. In particular, no mechanisms have been established to define the competencies to be trained in future engineers, in order to respond to SDGs and Industry 4.0 [8].

In this sense, to clarify the contribution of this study, its purpose to try to find answers to some interesting questions such as: What are the innovation characteristics required by new professionals in the engineering area? How can the elements of Industry 4.0 be introduced in the field of higher education? Is it possible to incorporate the objectives of sustainable development in the student training process? Finally: How is the concept of competence capable of integrating the aforementioned aspects, from a methodological perspective, in the training of professionals?

Focused on this last question adapting the classical structure of educational competence generation, this research presents a flow for the construction of innovation competences in engineering, integrating the requirements of industry 4.0 and the context and challenges of SDGs.

\section{Research Methodology}

The research method is organized in three stages: (1) Identification of innovation characteristics for engineering students; (2) Workflow for the construction of innovation skills for engineering students; (3) Application example. The research methodology used in this study presents an approach that combines aspects related to literature review, including an exhaustive analysis of different sources of information related to innovation characteristics, Industry 4.0 and Sustainable Development Goals, and, on the other hand, the construction of concrete results represented in a proposal to classify innovation skills and a workflow capable of integrating the aforementioned concepts, from which, as an example of the application of this, a set of definitions of competencies built on the basis of the proposed model is provided. Figure 1 shows the stages and specifies the research tools and activities, along with the results of each stage. 


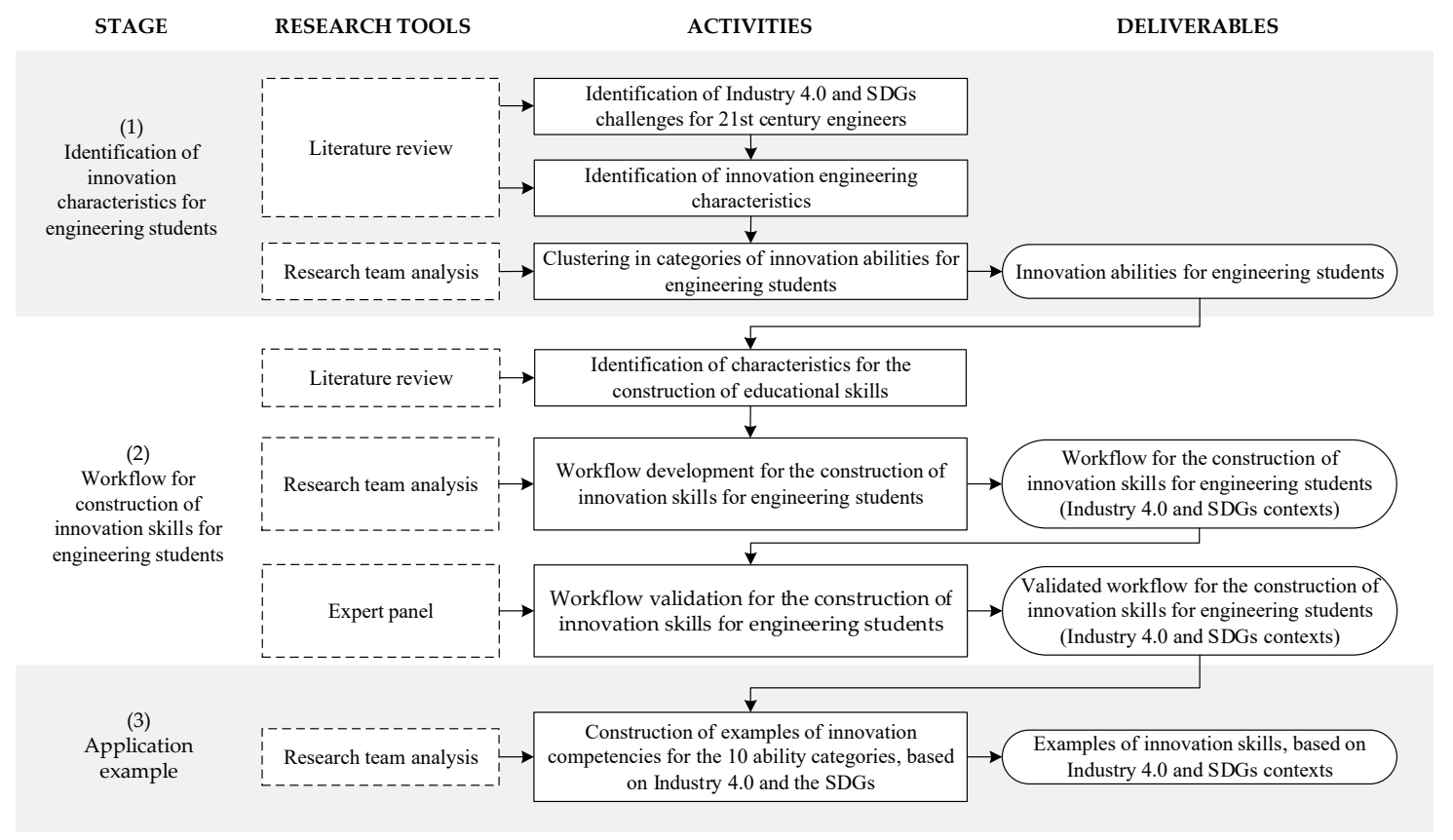

Figure 1. Research Methodology.

In the first stage, a literature review was carried out for the identification of the challenges of the Sustainable Development Goals (SDGs) and the requirements for new roles for Industry 4.0 professionals, along with the identification of characteristics of innovation in engineering. In order to identify these characteristics, it was necessary recognize some keywords, which were selected based on their relevance, frequency and application tendency. The search was carried out in the Web of Science and Scopus libraries, together with the incorporation of manuals on innovation from recognized entities in the area and university accreditation organizations. Documents were selected from the year 2000 to the present. The following search topics were considered: (a) Sustainable Development Goals-SDGs (challenges, implications); (b) Industry 4.0 (new professionals, challenges); and innovation in engineering (characteristics, skills, abilities). Later, based on the bibliographic support, the research team analyzed and categorized the innovation characteristics for engineering students. In the second stage, based on a new literature review (in the same collections already defined. Documents were selected from the year 2000 to the present. The following search topics were considered: innovation skills, learning outcomes, skills), characteristics for the construction of educational skills were identified. With this, the research team developed a workflow for the construction of innovation skills for engineering students (in Industry 4.0 and SDG contexts). Based on this, key innovation skills for engineering education were developed. These frameworks, and the skills considered in them, were validated by a panel of experts. Five experts were selected who met the following requirements: a) more than 10 years of practice in innovation activities, and b) experience as a consultant, researcher or university teacher in innovation topics, detailed in Table 1. Based on a focus group, the experts discussed the proposed key innovation skills. In the third stage, 10 examples of innovation competences were constructed, based on the developed workflow. 
Table 1. Characterization of the expert panel that validated the proposed workflow.

\begin{tabular}{|c|c|c|c|}
\hline Profession (Grade) & Occupation & Field of Work/Place & Years of Experience \\
\hline Civil Engineering, PhD & $\begin{array}{l}\text { Researcher and senior } \\
\text { consultant }\end{array}$ & $\begin{array}{l}\text { University education; } \\
\text { innovation in university } \\
\text { teaching. Spain }\end{array}$ & $>20$ \\
\hline Industrial Engineering, MBA & Professor and researcher & $\begin{array}{l}\text { Engineering education, } \\
\text { learning outcomes. Chile }\end{array}$ & $>15$ \\
\hline Civil Engineering, MSc & $\begin{array}{l}\text { Professor, researcher and } \\
\text { senior consultant }\end{array}$ & $\begin{array}{l}\text { Learning outcomes, } \\
\text { university education. Chile }\end{array}$ & $>20$ \\
\hline $\begin{array}{l}\text { Civil Engineering, } \mathrm{PhD} \\
\text { candidate }\end{array}$ & Professor and researcher & $\begin{array}{l}\text { Engineering education, } \\
\text { learning outcomes. Chile }\end{array}$ & $>10$ \\
\hline Computer Engineering, MBA & $\begin{array}{l}\text { Professor, researcher, project } \\
\text { management and consultant }\end{array}$ & $\begin{array}{l}\text { Engineering education, } \\
\text { learning outcomes. Chile }\end{array}$ & $\geq 20$ \\
\hline
\end{tabular}

\section{Literature Review}

\subsection{Industry 4.0}

The concept of Industry 4.0 originated in Germany, and describes the trend towards digitalization and automation of manufacturing environments [1]. The context considers, in general terms, the use of technology for more efficient production, which includes different aspects related to connectivity, applications, product as a service and even the customer experience. According to [9], Industry 4.0 "is the sum of all disruptive innovations derived and applied in a value chain to address trends in digitization, automation, transparency, mobility, modularization, networked collaboration and socialization of products and processes". Therefore, Industry 4.0 can implement an environment and provide a more intelligent service, making processes run smoothly in various industry sectors, having a wide range of applications. In this sense, technology takes a key role in many aspects, such as Internet of Things (IoT), use of digital sensors, data processing techniques, and many others.

Although Industry 4.0 is an established term in today's modern world, its meaning and implementation is still absent in some cases due to the lack of real awareness of people on these issues [2]. The advances will have a profound effect on society and individuals, as the production, integration and management of information systems will be improved.

One of the great challenges that organizations will have to overcome is increasing the technical capacity of their workers, since they will have to be able to analyze failures, overcome constant changes, learn new tasks and focus on problem solving. Therefore, training and continuous professional development will be a critical factor in the success of Industry 4.0, as it will not only change the occupations that workers currently perform, but also modify the skills frameworks [10]. Dynamic innovation will play an important role, as it provides the opportunity to develop new organizations and business models, leading to a higher degree of participation by representatives. In addition, the process of digitalization and virtualization ensures and presents several opportunities for manufacturers to develop new values and drive innovation. However, there are few studies in the field of engineering and management education regarding the training needs of university students who will be the workforce in this dynamic revolution that is taking place [8].

Connecting this concept with that of sustainability, industry 4.0 is directly related to the evolution of society, which has been involved in different revolutions, since the beginning of mass manufacturing, with the incorporation of electricity from energy as the main engine to support the process of production [10]. Nowadays, the incorporation of technologies, and the use of the internet towards the interconnection of various devices, goes beyond the conversion of data into information; the concept of sustainability joins industry 4.0, in the sense of a perspective that considers the full scope of business, social and environmental considerations. In this scenario, the potential for energy savings and efficiency, and the continuous and systematic control of processes, take special importance in order to detect possible problems at the right time, optimize the use of resources and introduce renewable energies to the production process, all in a sense of responding proactively rather than reactively [11]. 
In this way, the professionals who work in Industry 4.0 must know the business models as well as the techniques for analyzing large volumes of data, have an entrepreneurial spirit based on the characteristics of innovation, and lead new digital workers; above all, they must learn about the most disruptive technologies and their effect on the cost structure, and understand their impact on the organization now and in the future, with a great sense of responsibility towards preserving the environment [12].

\subsection{Sustainable Development Goals (SDGs)}

Governments have taken a leadership role and many have decided to start evolving towards Industry 4.0 [2]. It is therefore to be expected that such a transformation will take place in accordance with the objectives and goals that each country commits to fulfil both with its own nation and with the world at large. In this context, and based on the commitment made by a large number of countries, the initiatives for the development of industries in the 21st century are linked to the Sustainable Development Goals (SDGs) proposed by the United Nations. The SDGs are a set of objectives within a universal agreement that aim to address the empirical and scientific evidence that the world needs a more sustainable approach [3]. Consequently, the SDGs are intended to reflect the moral principles that no country or individual should ignore, with all being responsible for making the global vision a reality, and for articulating the sustainability challenges facing the world.

The goals are summarized in 17 targets, which provide a sufficiently scientifically sound, politically acceptable and publicly intuitive framework [4]. These goals are:

- Goal 1-No Poverty: economic growth must be inclusive to provide sustainable jobs and promote equality.

- Goal 2-Zero Hunger: the food and agriculture sector offers key solutions for development, and is central for hunger and poverty eradication.

- Goal 3-Good Health and Well-Being: ensuring healthy lives and promoting the well-being for all at all ages is essential to sustainable development.

- Goal 4-Quality Education: obtaining a quality education is the foundation to improving people's lives and sustainable development.

- Goal 5-Gender Equality: gender equality is not only a fundamental human right, but a necessary foundation for a peaceful, prosperous and sustainable world.

- Goal 6-Clean Water and Sanitation: clean, accessible water for all is an essential part of the world we want to live in.

- Goal 7-Affordable and Clean Energy: energy is central to nearly every major challenge and opportunity.

- Goal 8-Decent Work and Economic Growth: sustainable economic growth will require societies to create the conditions that allow people to have quality jobs.

- Goal 9-Industry, Innovation, and Infrastructure: investments in infrastructure are crucial to achieving sustainable development.

- Goal 10-Reduced Inequalities: to reduce inequalities, policies should be universal in principle, paying attention to the needs of disadvantaged and marginalized populations.

- Goal 11-Sustainable Cities and Communities: there needs to be a future in which cities provide opportunities for all, with access to basic services, energy, housing, transportation and more.

- Goal 12-Responsible Consumption and Production: responsible Production and Consumption.

- Goal 13-Climate Action: climate change is a global challenge that affects everyone, everywhere.

- Goal 14-Life below Water: careful management of this essential global resource is a key feature of a sustainable future.

- Goal 15-Life on Land: sustainable management of forests, combat desertification, halt and reverse land degradation, halt biodiversity loss. 
- Goal 16-Peace, Justice and Strong Institutions: access to justice for all, and building of effective and accountable institutions at all levels.

- Goal 17-Partnerships: revitalize the global partnership for sustainable development.

\subsection{Engineering Innovation}

Innovation, focused on the use of existing or new knowledge for the creation and/or improvement of new services, processes or products, obtaining original results of high social or economic value, which respond to the challenges of sustainability and fit into current and future technological environments, is key [3]. With this, innovation skills will be essential for the successful inclusion of professionals in Industry 4.0, providing a possibility of development framed by the new development goals [13].

In the area of engineering, many authors have indicated the characteristics that innovative engineers should have. In this context, 20 characteristics of innovation have been identified that an engineering professional should possess [6,14-22]:

- Adapter (energetic, active to learn, do and remake, positively accepting the opinion of others).

- Multiple alternatives seeker (capable of looking for a better way to execute a process, design or manufacture a product).

- Experimenter (capable of accepting uncertainty, using the creation of prototypes to evaluate the options).

- Knowledge integrator (capable of integrating one's own knowledge with that of the team and technician to build new solutions).

- Deep Knowledge (educated professional with knowledge of a wide range of topics).

- Curious about doing and learning (reflective professional, constantly looking for new ideas and solutions).

- Communicator (able to effectively communicate ideas and persuade others).

- Responsible (able to take control of his or her activities and oversee a project from start to finish, responding to results and accepting possible mistakes).

- Persistent (committed, determined, resilient. He/she is convinced that he/she will achieve his/her objectives).

- Passionate (professional who is passionate about his/her work and the objectives he/she has achieved, transmitting his/her passion to his/her team).

- Collaborative and integrative (able to collaborate with others with specific knowledge and skills, to successfully achieve an innovation).

- Creative (able to generate new ideas or associations between ideas to produce original solutions).

- Risk-taker (willing to take risks and fail).

- Visionary (professional with a clear vision and objectives).

- Challenging (willing to do things differently, questioning traditional methods).

- Team leader and manager (professional who is a team leader and manager, facilitating and driving innovation).

- Implementer (who efficiently organizes and manages resources to develop an innovation).

- Analytical (meticulous, examining carefully).

- Business savvy (who knows the role of finance, sales, supply chains and the innovation market).

- User-focused (who seeks solutions focused on user needs).

Table 2 shows the evidence identified for each of the 20 characteristics of innovation in engineering, according to the literature studied. 
Table 2. Evidence identified for each of the 20 characteristics of innovation in engineering.

\begin{tabular}{|c|c|c|c|c|c|c|c|c|c|c|c|c|c|c|c|c|c|c|c|c|}
\hline Review Article & 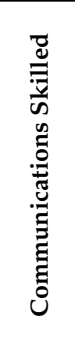 & 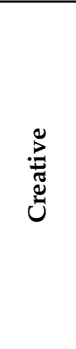 & 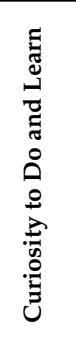 & 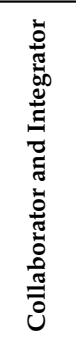 & 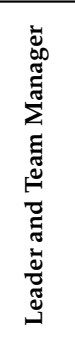 & 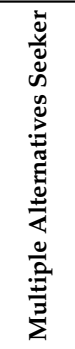 & 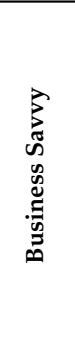 & 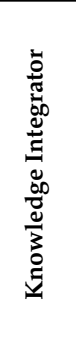 & 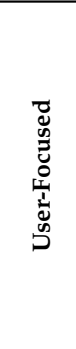 & $\begin{array}{l}\stackrel{\Xi}{\Xi} \\
\stackrel{0}{0} \\
\stackrel{5}{>}\end{array}$ & 宽 & 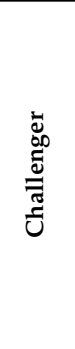 & 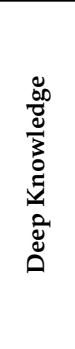 & $\begin{array}{l}\overrightarrow{\mathrm{J}} \\
\frac{\mathrm{a}}{\mathrm{\sigma}} \\
\frac{\sigma}{4}\end{array}$ & 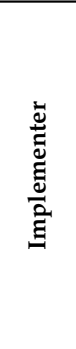 & 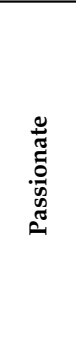 & 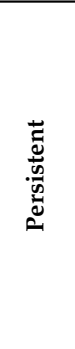 & $\begin{array}{l}\frac{0}{0} \\
\frac{0}{0} \\
\tilde{0} \\
\stackrel{0}{0} \\
\stackrel{0}{0}\end{array}$ & 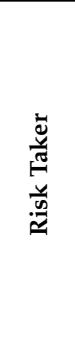 & 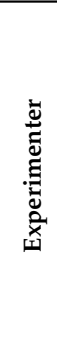 \\
\hline Edwards et al. [23] & $x$ & $\mathrm{x}$ & & $x$ & $x$ & & $\mathrm{x}$ & $\mathrm{x}$ & & $x$ & $x$ & $\mathrm{x}$ & & & & $x$ & & $x$ & & \\
\hline Ferguson et al. [6] & $\mathrm{x}$ & $\mathrm{x}$ & $\mathrm{x}$ & $\mathrm{x}$ & $\mathrm{x}$ & $\mathrm{x}$ & $\mathrm{x}$ & $\mathrm{x}$ & $\mathrm{x}$ & $\mathrm{x}$ & $\mathrm{x}$ & $\mathrm{x}$ & $\mathrm{x}$ & $\mathrm{x}$ & $\mathrm{x}$ & $\mathrm{x}$ & $\mathrm{x}$ & & $\mathrm{x}$ & $\mathrm{x}$ \\
\hline Holzmann [24] & & $\mathrm{x}$ & $\mathrm{x}$ & & & $\mathrm{x}$ & & & & $\mathrm{x}$ & & $\mathrm{x}$ & & & & & & $\mathrm{x}$ & & \\
\hline Satheesh et al. [25] & $\mathrm{x}$ & $\mathrm{x}$ & $\mathrm{x}$ & & & & $\mathrm{x}$ & & $\mathrm{x}$ & & & $\mathrm{x}$ & $\mathrm{x}$ & & $\mathrm{x}$ & $\mathrm{x}$ & & $\mathrm{x}$ & & \\
\hline Pitso [26] & & $\mathrm{x}$ & $\mathrm{x}$ & & & $\mathrm{x}$ & & & & & & $\mathrm{x}$ & $\mathrm{x}$ & & & & $\mathrm{x}$ & $\mathrm{x}$ & $\mathrm{x}$ & $\mathrm{x}$ \\
\hline Galego et al. [27] & & & & & & & $\mathrm{x}$ & & & $\mathrm{x}$ & & & & & & & $\mathrm{x}$ & & $\mathrm{x}$ & \\
\hline Edwards-Schachter et al [15] & $\mathrm{x}$ & $\mathrm{x}$ & $\mathrm{x}$ & $\mathrm{x}$ & $\mathrm{x}$ & $\mathrm{x}$ & $\mathrm{x}$ & $\mathrm{x}$ & $\mathrm{x}$ & $\mathrm{x}$ & $\mathrm{x}$ & $\mathrm{x}$ & $\mathrm{x}$ & $\mathrm{x}$ & $\mathrm{x}$ & $\mathrm{x}$ & $\mathrm{x}$ & $\mathrm{x}$ & $\mathrm{x}$ & $\mathrm{x}$ \\
\hline Cao et al. [28] & $\mathrm{x}$ & & & $\mathrm{x}$ & $\mathrm{x}$ & & $\mathrm{x}$ & & $\mathrm{x}$ & & & & & & & & & & & \\
\hline Zuo [29] & $\mathrm{x}$ & & $\mathrm{x}$ & $\mathrm{x}$ & $\mathrm{x}$ & & & & & & $\mathrm{x}$ & & $\mathrm{x}$ & & & $\mathrm{x}$ & & & & $\mathrm{x}$ \\
\hline Garud et al. [30] & & & & & & $\mathrm{x}$ & $\mathrm{x}$ & & $\mathrm{x}$ & $\mathrm{x}$ & $\mathrm{x}$ & $\mathrm{x}$ & & $\mathrm{x}$ & & & & $\mathrm{x}$ & & \\
\hline Palavicini and Cepeda [31] & $\mathrm{x}$ & $x$ & $\mathrm{x}$ & $\mathrm{x}$ & & $\mathrm{x}$ & & & $\mathrm{x}$ & $\mathrm{x}$ & & & & & $\mathrm{x}$ & $\mathrm{x}$ & & & & \\
\hline Jarrar and Anis [21] & $\mathrm{x}$ & $\mathrm{x}$ & $\mathrm{x}$ & $\mathrm{x}$ & $\mathrm{x}$ & $\mathrm{x}$ & $\mathrm{x}$ & $\mathrm{x}$ & $\mathrm{x}$ & & $\mathrm{x}$ & $\mathrm{x}$ & $\mathrm{x}$ & $\mathrm{x}$ & $\mathrm{x}$ & & $\mathrm{x}$ & $\mathrm{x}$ & $\mathrm{x}$ & $\mathrm{x}$ \\
\hline Poveda et al. [32] & & $\mathrm{x}$ & & $\mathrm{x}$ & $\mathrm{x}$ & $\mathrm{x}$ & $\mathrm{x}$ & $\mathrm{x}$ & $\mathrm{x}$ & $\mathrm{x}$ & & $\mathrm{x}$ & & $\mathrm{x}$ & $\mathrm{x}$ & & $\mathrm{x}$ & & & \\
\hline Lounsbury et al. [22] & $\mathrm{x}$ & $\mathrm{x}$ & $\mathrm{x}$ & $\mathrm{x}$ & $\mathrm{x}$ & $\mathrm{x}$ & $\mathrm{x}$ & $\mathrm{x}$ & $\mathrm{x}$ & $\mathrm{x}$ & $\mathrm{x}$ & $\mathrm{x}$ & $\mathrm{x}$ & $\mathrm{x}$ & $\mathrm{x}$ & $\mathrm{x}$ & $\mathrm{x}$ & $\mathrm{x}$ & $\mathrm{x}$ & $\mathrm{x}$ \\
\hline Hebles and Llanos-Contreras [20] & $\mathrm{x}$ & $\mathrm{x}$ & $\mathrm{x}$ & $\mathrm{x}$ & $\mathrm{x}$ & $\mathrm{x}$ & $\mathrm{x}$ & & $\mathrm{x}$ & $\mathrm{x}$ & $\mathrm{x}$ & $\mathrm{x}$ & & $\mathrm{x}$ & $\mathrm{x}$ & $\mathrm{x}$ & $\mathrm{x}$ & $\mathrm{x}$ & $\mathrm{x}$ & $\mathrm{x}$ \\
\hline Radharamanan and Juang [33] & & $\mathrm{x}$ & & & & $\mathrm{x}$ & $\mathrm{x}$ & $\mathrm{x}$ & $\mathrm{x}$ & & $\mathrm{x}$ & $\mathrm{x}$ & $\mathrm{x}$ & $\mathrm{x}$ & $\mathrm{x}$ & $\mathrm{x}$ & $\mathrm{x}$ & & $\mathrm{x}$ & $\mathrm{x}$ \\
\hline Schuelke-Leech [34] & $\mathrm{x}$ & $\mathrm{x}$ & $\mathrm{x}$ & & $\mathrm{x}$ & & $\mathrm{x}$ & $\mathrm{x}$ & & $\mathrm{x}$ & & & $\mathrm{x}$ & & & & $\mathrm{x}$ & & & \\
\hline Shuli et al. [18] & $\mathrm{x}$ & $\mathrm{x}$ & $\mathrm{x}$ & $\mathrm{x}$ & $\mathrm{x}$ & $\mathrm{x}$ & $\mathrm{x}$ & $\mathrm{x}$ & $\mathrm{x}$ & $\mathrm{x}$ & $\mathrm{x}$ & $\mathrm{x}$ & $\mathrm{x}$ & $\mathrm{x}$ & $\mathrm{x}$ & $\mathrm{x}$ & $\mathrm{x}$ & $\mathrm{x}$ & $\mathrm{x}$ & $\mathrm{x}$ \\
\hline Bilén et al. [14] & $\mathrm{x}$ & $\mathrm{x}$ & $\mathrm{x}$ & $\mathrm{x}$ & $\mathrm{x}$ & $\mathrm{x}$ & $\mathrm{x}$ & $\mathrm{x}$ & $\mathrm{x}$ & $\mathrm{x}$ & $\mathrm{x}$ & $\mathrm{x}$ & $\mathrm{x}$ & $\mathrm{x}$ & $\mathrm{x}$ & $\mathrm{x}$ & $\mathrm{x}$ & $\mathrm{x}$ & $\mathrm{x}$ & $\mathrm{x}$ \\
\hline Browder et al. [35] & $\mathrm{x}$ & $\mathrm{x}$ & $\mathrm{x}$ & $\mathrm{x}$ & & & & $\mathrm{x}$ & $\mathrm{x}$ & & & $\mathrm{x}$ & & $\mathrm{x}$ & $\mathrm{x}$ & $\mathrm{x}$ & $\mathrm{x}$ & & & $\mathrm{x}$ \\
\hline Creed et al. [36] & $\mathrm{x}$ & $\mathrm{x}$ & & $\mathrm{x}$ & $\mathrm{x}$ & $\mathrm{x}$ & $\mathrm{x}$ & $\mathrm{x}$ & $\mathrm{x}$ & & $\mathrm{x}$ & & $\mathrm{x}$ & $\mathrm{x}$ & $\mathrm{x}$ & $\mathrm{x}$ & & & $\mathrm{x}$ & $\mathrm{x}$ \\
\hline Huang-Saad et al. [37] & $\mathrm{x}$ & $\mathrm{x}$ & $\mathrm{x}$ & $\mathrm{x}$ & $\mathrm{x}$ & $\mathrm{x}$ & $\mathrm{x}$ & $\mathrm{x}$ & $\mathrm{x}$ & $\mathrm{x}$ & $\mathrm{x}$ & & $\mathrm{x}$ & $\mathrm{x}$ & & & $\mathrm{x}$ & $\mathrm{x}$ & $\mathrm{x}$ & \\
\hline Mayhew et al. [16] & $\mathrm{x}$ & $\mathrm{x}$ & $\mathrm{x}$ & $\mathrm{x}$ & $\mathrm{x}$ & $\mathrm{x}$ & $\mathrm{x}$ & $x$ & $\mathrm{x}$ & $\mathrm{x}$ & $\mathrm{x}$ & $\mathrm{x}$ & $\mathrm{x}$ & $\mathrm{x}$ & $\mathrm{x}$ & $\mathrm{x}$ & $\mathrm{x}$ & $\mathrm{x}$ & $\mathrm{x}$ & $\mathrm{x}$ \\
\hline Mendelson [38] & $\mathrm{x}$ & $\mathrm{x}$ & $\mathrm{x}$ & $\mathrm{x}$ & $\mathrm{x}$ & & $\mathrm{x}$ & $\mathrm{x}$ & $\mathrm{x}$ & & $\mathrm{x}$ & & & & & & & $\mathrm{x}$ & & $\mathrm{x}$ \\
\hline Oswald [17] & $\mathrm{x}$ & $\mathrm{x}$ & $\mathrm{x}$ & $\mathrm{x}$ & $\mathrm{x}$ & $\mathrm{x}$ & $\mathrm{x}$ & $\mathrm{x}$ & $\mathrm{x}$ & $\mathrm{x}$ & $\mathrm{x}$ & $\mathrm{x}$ & $\mathrm{x}$ & $\mathrm{x}$ & $\mathrm{x}$ & $\mathrm{x}$ & $\mathrm{x}$ & $\mathrm{x}$ & $\mathrm{x}$ & $\mathrm{x}$ \\
\hline Selznick and Mayhew [39] & $\mathrm{x}$ & $\mathrm{x}$ & $\mathrm{x}$ & $\mathrm{x}$ & $\mathrm{x}$ & & & $\mathrm{x}$ & & $\mathrm{x}$ & & & & $\mathrm{x}$ & $\mathrm{x}$ & $\mathrm{x}$ & & $\mathrm{x}$ & $\mathrm{x}$ & $\mathrm{x}$ \\
\hline Taks et al. [40] & $\mathrm{x}$ & $\mathrm{x}$ & $\mathrm{x}$ & $\mathrm{x}$ & $\mathrm{x}$ & $\mathrm{x}$ & $\mathrm{x}$ & $\mathrm{x}$ & $\mathrm{x}$ & $\mathrm{x}$ & $\mathrm{x}$ & $\mathrm{x}$ & $\mathrm{x}$ & $\mathrm{x}$ & $\mathrm{x}$ & $\mathrm{x}$ & $\mathrm{x}$ & $\mathrm{x}$ & $\mathrm{x}$ & $\mathrm{x}$ \\
\hline Wang and Kleppe [41] & $\mathrm{x}$ & $\mathrm{x}$ & $\mathrm{x}$ & $\mathrm{x}$ & $\mathrm{x}$ & $\mathrm{x}$ & & $\mathrm{x}$ & & & $\mathrm{x}$ & & $\mathrm{x}$ & $\mathrm{x}$ & $\mathrm{x}$ & $\mathrm{x}$ & $\mathrm{x}$ & & $\mathrm{x}$ & $\mathrm{x}$ \\
\hline Xu et al. [42] & $\mathrm{x}$ & & & & $\mathrm{x}$ & $\mathrm{x}$ & $\mathrm{x}$ & $\mathrm{x}$ & $\mathrm{x}$ & & $\mathrm{x}$ & & $\mathrm{x}$ & & & & & & $\mathrm{x}$ & \\
\hline Hables et al. [43] & $\mathrm{x}$ & & $\mathrm{x}$ & $\mathrm{x}$ & $\mathrm{x}$ & $\mathrm{x}$ & & $\mathrm{x}$ & & $\mathrm{x}$ & & & $\mathrm{x}$ & & & & & $\mathrm{x}$ & & \\
\hline Sánchez et al. [44] & $x$ & $x$ & $x$ & $x$ & $x$ & $\mathrm{x}$ & & $x$ & $x$ & $x$ & & $\mathrm{x}$ & & $x$ & $x$ & $x$ & $x$ & $x$ & $x$ & $x$ \\
\hline$\%$ of presence in the literature review & $81 \%$ & $81 \%$ & $74 \%$ & $74 \%$ & $74 \%$ & $71 \%$ & $71 \%$ & $71 \%$ & $71 \%$ & $65 \%$ & $61 \%$ & $61 \%$ & $61 \%$ & $61 \%$ & $61 \%$ & $61 \%$ & $61 \%$ & $61 \%$ & $61 \%$ & $61 \%$ \\
\hline
\end{tabular}




\subsection{Engineering Innovation Skills}

The innovation characteristics incorporated in the context of industry 4.0 must consider soft skills and technological competences [45]. The former focus on the competences that the industry requires to assume positions associated with teamwork, leadership, effective communication, knowledge of the area, negotiation and business skills, service and achievement orientation, analytical thinking, problem solving, interpersonal relationships, and decision making, among others [45-47]. The latter focuses on technological skills, which are associated with the ability to search for digital information and digital literacy, the use of technologies for communication processes and interaction of digital resources and content creation, computer programming, the design and development of digital content, data and information security, and technical problem solving [5].

In these contexts, innovation training for engineering students is key, and must be aligned with the relevant challenges [48]. This is indicated by international accreditation bodies, which point out that innovation capacity and creativity must be taken into account in all of the training of future engineers [49]. Universities should respond to these requirements and establish a structure to guide the teaching of these topics. To this end, engineering careers require the incorporation of innovation skills training, which must be built according to established educational methodologies [50-52].

A competence in education is a set of social, affective behaviors and cognitive, psychological, sensory and motor skills that enable the adequate performance in fulfilling a role, activity or task [53]. There are several studies for the denomination of a competence [54] in the context of higher education, from which it is possible to identify four transversal aspects: (1) Domain of action: this indicates the level of complexity of an object of study, referring to the degree of appropriation of the conceptual construct. In this context, Bloom's taxonomy, and its updating by Anderson, establishes hierarchical models to classify learning objectives at different levels of complexity, which depend on the acquisition of knowledge and different skills [55]; (2) Know: body of knowledge that characterizes the discipline. They may be knowledge, model development, application of techniques, use of instruments, use of resources or other professional products, among others; (3) Knowledge to be: demonstrates the attitudinal part in the application of knowledge and skills (knowledge), which gives the professional a different trait in the application and therefore a distinctive significance in the results obtained. It should reflect a transversal denomination of their training, beyond their own disciplinary area. It shows attitudes and values that allow the identification of a distinctive feature in the training; (4) Know-to do: it comprises, on the one hand, the space (context) where the professional is inserted to develop his/her performance. These can be in a global context (institutions, public and/or private sector) or specific areas, as well as quality reference (performance condition), reflected by the position the professional takes when faced with a given situation [56]. Figure 2 shows the scheme of interaction of the above-mentioned elements in the construction of a competition.

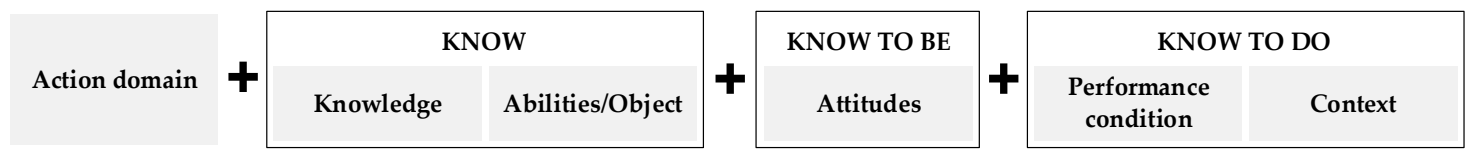

Figure 2. Scheme of interaction of elements for the skill construction.

\section{Results and Discussion}

Based on the background described above, this section proposes a model that integrates, on the one hand, the SDGs in the context of Industry 4.0 and, on the other, the innovation skills in the field of engineering and the scheme of integration of elements in the construction of competition.

Figure 3 shows the proposed flow for the construction of engineering innovation competences in the context of Industry 4.0 and SDGs. It contains, at the top, the 17 sustainable development objectives and the relevant elements of Industry 4.0. From them, it is possible to link the 20 characteristics of innovative engineering professionals, which have converged in 10 skills grouped in 4 categories: 
(1) Technical or Practical; (2) Interpersonal or Social; (3) Reasoning; (4) Management or Business. Considering the above, the elements that interact in the identification of a competence are integrated in order to build innovation competences. In this way, it is possible to connect the aspects of the scheme in Figure 2, where "know" and "know-to be" are related to the categories identified from the characteristics of innovative engineers, and "know-to do" is related to the elements of industry 4.0 and ODS, reflecting their impact on the context and performance condition.

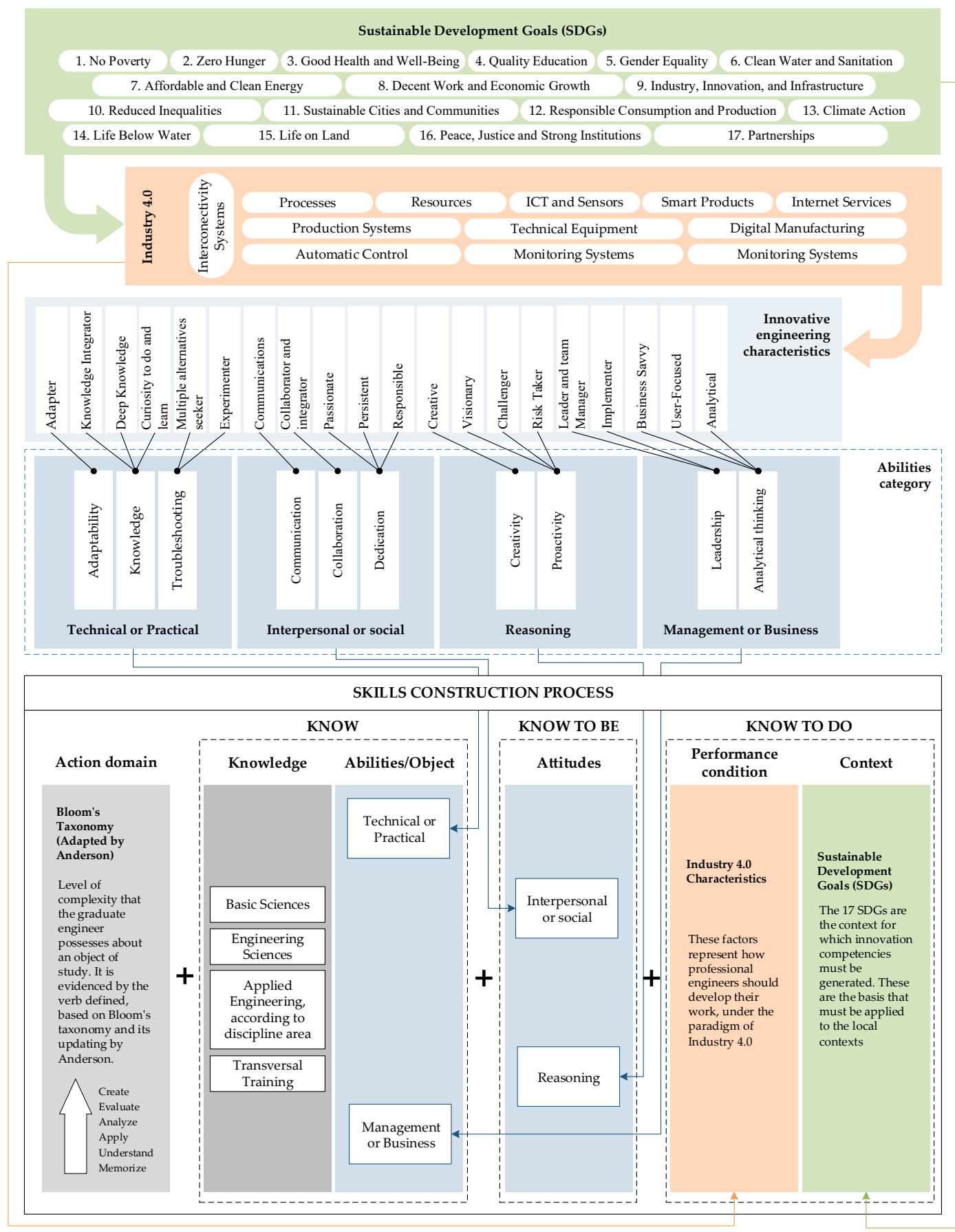

Figure 3. Proposed workflow for the construction of engineering innovation competences in the context of Industry 4.0 and SDGs.

Based on the previous scheme, considering the concepts of the SDGs and elements related to Industry 4.0, a set of 10 innovation skills examples is presented in the Table 3, associated with the 
abilities categories of innovation characteristics, which can be considered a starting point to incorporate into the curricula for engineering students.

Table 3. Examples of innovation skills, based on Industry 4.0 and SDGs contexts.

\begin{tabular}{|c|c|c|}
\hline Type & Abilities Characteristics (AC) & Skills (S) Example \\
\hline \multirow{3}{*}{ Technical or Practical } & Adaptability & $\begin{array}{l}\text { To analyze situations of the environment, applying strategies to create } \\
\text { or improve products and services, facing changes with flexibility and } \\
\text { constructively promoting the sustainable growth of society. }\end{array}$ \\
\hline & Knowledge & $\begin{array}{l}\text { To integrate knowledge from the area of science, engineering and } \\
\text { industry, autonomously and with the capacity for abstraction, for the } \\
\text { continuous improvement of physical and virtual processes in order to } \\
\text { promote the well-being of all kinds of communities. }\end{array}$ \\
\hline & Troubleshooting & $\begin{array}{l}\text { To evaluate, select and use resources, tools and technologies from the } \\
\text { field of industry and engineering, to transform problems into } \\
\text { opportunities, in order to design methods and models of the service of } \\
\text { automation and control in sustainable production processes. }\end{array}$ \\
\hline \multirow{3}{*}{ Interpersonal or social } & Communication & $\begin{array}{l}\text { To express ideas clearly and adapt depending on the informative } \\
\text { purpose, using appropriate language and recognizing the importance of } \\
\text { communication skills in personal and integral development to achieve } \\
\text { the settlement of people in multicultural contexts. }\end{array}$ \\
\hline & Collaboration & $\begin{array}{l}\text { To participate in multidisciplinary work environments, incorporating } \\
\text { social, cultural and environmental aspects, opting for group interest } \\
\text { over personal, to carry out predictive planning in relation to the access } \\
\text { and use of reliable energies for everyone in the same way. }\end{array}$ \\
\hline & Dedication & $\begin{array}{l}\text { To focus actions to comply with commitments undertaken, effectively } \\
\text { managing time and planning activities to achieve the objectives of } \\
\text { sustainable development, within the established deadlines and in the } \\
\text { context of an inclusive, equal and fair society. }\end{array}$ \\
\hline \multirow{2}{*}{ Reasoning } & Creativity & $\begin{array}{l}\text { To design alternative solutions to model industry systems and processes, } \\
\text { finding learning opportunities in the problems and generating new } \\
\text { ideas that allow responding to future demands of the environment and } \\
\text { that promote an efficient and sustainable use of ecosystem resources. }\end{array}$ \\
\hline & Proactivity & $\begin{array}{l}\text { To demonstrate initiative in facing situations in the environment, } \\
\text { seeking opportunities to innovate in organizational services and } \\
\text { production systems, generating interdisciplinary work networks, } \\
\text { promoting inclusive and sustainable industrialization. }\end{array}$ \\
\hline \multirow{2}{*}{ Management or Business } & Leadership & $\begin{array}{l}\text { To manage projects and work in teams, assigning tasks according to } \\
\text { resources, applying tools and techniques to promote the achievement of } \\
\text { individual objectives and therefore the growth of the organization as a } \\
\text { whole integrated system. }\end{array}$ \\
\hline & Analytical thinking & $\begin{array}{l}\text { To plan studies and conduct research in order to analyze situations with } \\
\text { the capacity for abstraction, synthesis and critical reflection, to solve } \\
\text { problems in the field of engineering applied to industry, in the service of } \\
\text { the sustainable development of society. }\end{array}$ \\
\hline
\end{tabular}

The workflow proposed, as well as the competencies identified from it, are inserted into the training process for students, who belong to some quite special generations in terms of understanding the environment, ranging from the incorporation of technologies in different aspects of their lives up to the instantaneous availability of information and services both in their daily work and in the educational field. In concrete terms, the model and competencies should be applied to students belonging to Gen $Y$ and Gen Z, who have individual characteristics [57]. Gen Y denominates Millennials, which is comprised of people in both elementary school and high school, who might be the same generation, but they have very different views and needs. Gen Z was born together with ICT; many of them grew up playing with their parents' mobile phones or tablets. Both generations have grown up in a hyper-connected world and the smartphone is their preferred method of communication [58-60]. In this sense, their conception of the world is somewhat limited by the individuality of the vision of their own world, formed by beliefs about others that they base on the information they have at their disposal, but, in many cases, they are not able to process them adequately [61,62]. Considering the previous points, although innovation seems to be a more natural aspect related to the use of technology, social responsibility in the performance of actions is an aspect that requires a greater effort to incorporate in the training of students, a challenge that needs to be faced in higher education [63]. 
In this sense, the incorporation of the identified competences could be considered as the basis of the curricular redesign processes, from the declaration of the graduation profile, to the definition of the learning results that will allow the demonstration of the appropriation of knowledge, skills and attitudes in the performance of future professionals.

\section{Conclusions}

This study identifies the relevant aspects of the Industry 4.0, associated with digitalization, automation, connectivity and efficient production, focusing on the impact of these characteristics in professionals. These aspects are framed within the challenges of Sustainable Development Goals (SDGs), serving as a basis for the identification of new characteristics and abilities that engineers will require. This research includes a categorization of the innovation characteristics, obtained in the literature review, which includes definitions from several authors, and also this study provides concrete examples of each innovation category proposed, which should be considered as the starting point to introduce important aspects considering industries, environment and education as a complex integration of today's requirements and future needs.

In this work, the authors have proposed a model for the construction of engineering innovation skills, which represents an interesting approach to integrate concepts related to the Sustainable Development Goals (SDGs) and industry 4.0 contexts, in order to incorporate them in the scope of the university education process. Thus, the workflow described has demonstrated an alternative way to consider these concepts in the redesign or adjustment of the curriculum and is a guideline to define the skills necessary for the engineering profiles declared. In other words, the knowledge, abilities and attitudes required to face the challenges and needs for the current society in the innovation environment.

Another important aspect of this study points out that the proposed workflow is based on characteristics of innovation, and on the incorporation of sustainable development objectives, which are cross-cutting elements of current student training processes; therefore, its application could be considered beyond the field of engineering, towards other disciplines that prepare professionals to face the problems of society and the challenges that Industry 4.0 considers.

Finally, in future work, the authors plan to go deeper into the methods to evaluate these kinds of skills, in order to explore the effectiveness of their incorporation into engineering study programs, and allow the students to contribute to environmentally friendly practices in their professional performance to reach interdisciplinary objectives.

Author Contributions: This paper represents the results of teamwork. P.H. and F.M.-L.R. designed the research methodology. J.D., D.E. and F.M.-L.R. carried out the background research. All of the authors worked on the results, discussion and conclusions the manuscript. Finally, P.H. and F.M.-L.R. reviewed and edited the manuscript. All authors have read and agreed to the published version of the manuscript.

Funding: This research was conducted thanks to the contributions of the CORFO Project 14ENI2-26905 Ingeniería 2030-PUCV. This research was funded by CONICYT grant number CONICYT-PCHA/International Doctorate/ 2019-72200306 for funding the graduate research of Muñoz-La Rivera.

Acknowledgments: The authors acknowledge the Valparaíso Makerspace and the Collaborative Group of Engineering Education (CGEE) from Pontificia Universidad Católica de Valparaíso (Chile).

Conflicts of Interest: The authors declare no conflict of interest.

\section{References}

1. Oesterreich, T.D.; Teuteberg, F. Computers in Industry Understanding the implications of digitisation and automation in the context of Industry 4.0: A triangulation approach and elements of a research agenda for the construction industry. Comput. Ind. 2016, 83, 121-139. [CrossRef]

2. Rejikumar, G.; Raja, V.; Arunprasad, P.; Persis, J.; Sreeraj, K. Industry 4.0: Key findings and analysis from the literature arena. Int. J. 2019, 2626, 2514-2542.

3. Mian, S.H.; Salah, B.; Ameen, W.; Moiduddin, K.; Alkhalefah, H. Adapting Universities for Sustainability Education in Industry 4.0: Channel of Challenges and Opportunities. Sustainability 2020, 12, 6100. [CrossRef] 
4. United Nations. Transforming our World: The 2030 Agenda for Sustainable Development. 2015. Available online: https://sustainabledevelopment.un.org/post2015/transformingourworld (accessed on 12 August 2020).

5. Cabaña, A.; Galbusera, L.; Fornari, J. Industria 4.0: Competencias en carreras de ingeniería. AJEA 2019, 1, $1-10$.

6. Ferguson, D.M.; Jablokow, K.W.; Ohland, M.W. Identifying the Characteristics of Engineering Innovativeness Identifying the Characteristics of Engineering Innovativeness. Eng. Stud. 2017, 9, 45-73. [CrossRef]

7. Hermosilla, P.; Muñoz-La Rivera, F.; Echeverría, D.; Cofré, C.; Perazzo, F.; Delgadillo, J. A Proposal Of An Instrument To Evaluate Innovation Characteristics for Engineering Students. Int. J. Adv. Sci. Technol. 2020, 29, 579-590.

8. Liao, Y.; Deschamps, F.; De Freitas, E.; Loures, R. Past, present and future of Industry 4.0-A systematic literature review and research agenda proposal. Int. J. Prod. Res. 2017, 55, 3609-3629. [CrossRef]

9. Mohamed, M. Challenges and Benefits of Industry 4.0: An overview. Int. J. Supply Oper. Manag. 2018, 5, 256-265.

10. Da Xu, L.; Xu, E.L.; Li, L. Industry 4.0: State of the art and future trends. Int. J. Prod. Res. 2018, 56, $2941-2962$.

11. Oláh, J.; Aburumman, N.; Popp, J.; Asif-Khan, M.; Haddad, H.; Kitukutha, N. Impact of Industry 4.0 on Environmental Sustainability. Sustainability 2020, 12, 4674. [CrossRef]

12. Digital Business Models for Industrie 4.0, Plattform Industrie 4.0-Bertolt-Brecht-Platz 3, 10117 Berlin, February 2019. Available online: https:/www.bmwi.de/Redaktion/EN/Publikationen/Industry/digitalbusiness-models-industry-4-0.pdf?_blob=publicationFile\&v=3 (accessed on 12 August 2020).

13. Toner, P. Workforce Skills and Innovation: An Overview of Major Themes in the Literature; OECD Publications: Paris, France, 2011.

14. Bilén, S.; Kisenwether, E.; Rzasa, S.; Wise, J. Developing and Assessing Students' Entrepreneurial Skills and Mind-Set*. J. Eng. Educ. 2005, 94, 233-243. [CrossRef]

15. Edwards-Schachter, M.; García-Granero, A.; Sánchez-Barrioluengo, M.; Quesada, H.; Amara, N. Disentangling competences: Interrelationships on creativity, innovation and entrepreneurship. Think. Ski. Creat. 2015, 16, 27-39. [CrossRef]

16. Mayhew, M.J.; Simonoff, J.S.; Baumol, W.J.; Wiesenfeld, B.M.; Klein, M.W. Exploring Innovative Entrepreneurship and Its Ties to Higher Educational Experiences. Res. High. Educ. 2012, 53, 831-859. [CrossRef]

17. Oswald, M. Integrating Innovation and Entrepreneurship Principles into the Civil Engineering Curriculum. J. Prof. Issues Eng. Educ. Pract. 2015, 141, 04014014. [CrossRef]

18. Shuli, Z.; Hua, Z.; Junlin, W. Cognition and System Construction of Civil Engineering Innovation and Entrepreneurship System in Emerging Engineering Education. Cogn. Syst. Res. 2018, 52, 1020-1028.

19. Urquizo, H.G. Propuesta de medición y evaluación de Resultados de Aprendizaje según criterios de ABET y ASIIN. In Proceedings of the 16th LACCEI International Multi-Conference for Engineering, Education, and Technology, Lima, Peru, 19-21 July 2018.

20. Hebles, M.; Llanos-Contreras, O. Evolución percibida de la competencia para emprender a partir de la implementación de un programa de formación de competencias en emprendimiento e innovación. REOP 2019, 30, 9-26. [CrossRef]

21. Jarrar, M.; Anis, H. The Impact of Entrepreneurship on Engineering Education. In Proceedings of the 2016 Canadian Engineering Education Association, Halifax, NS, Canada, 19-22 June 2016; pp. 2-7.

22. Lounsbury, M.; Cornelissen, J.; Granqvist, N.; Grodal, S. Culture, innovation and entrepreneurship. Innovation 2018, 21, 1-12. [CrossRef]

23. Edwards, M.; Sánchez-ruiz, L.M.; Tovar-caro, E.; Ballester-sarrias, E. Engineering Students' Perceptions of Innovation and Entrepreneurship Competences. In Proceedings of the 39th ASEE/IEEE Frontiers in Education Conference, San Antonio, TX, USA, 18-21 October 2009.

24. Holzmann, P.; Hartlieb, E.; Roth, M. From Engineer to Entrepreneur-Entrepreneurship Education for Engineering Students: The Case of the Entrepreneurial Campus Villach. Int. J. Eng. Ped. 2018, 8, 28-39. [CrossRef]

25. Satheesh, G.; Suman, N.; Ramgopal, N.C. Entrepreneurship and Innovation: A Study on Factors Affecting Engineering Graduates towards Entrepreneurship and Innovation. J. Eng. Educ. Transform. 2015, 1707, 170-174. [CrossRef]

26. Pitso, T. An Integrated Model for Invigorating Innovation and Entrepreneurship in Higher Education. In Innovations in Higher Education —Cases on Transforming and Advancing Practice; IntechOpen: London, UK, 2019. 
27. Galego, D.; Amorim, M.; Dias, M.F.; Sarmento, M. Barriers of Social Innovation in Academic Curricula. In Proceedings of the 8th International Conference The Future of Education, Florence, Italy, 28-29 June 2018.

28. Cao, D.; Li, H.; Wang, G.; Luo, X.; Tan, D. Relationship Network Structure and Organizational Competitiveness: Evidence from BIM Implementation Practices in the Construction Industry. J. Manag. Eng. 2018, 34, 04018005. [CrossRef]

29. Zuo, J. Exploration and Research on the Cultivation Mode of Innovation and Entrepreneurship of Engineering Students in Colleges and Universities. J. Educ. Theory Manag. 2017, 88-90. [CrossRef]

30. Garud, R.; Gehman, J.; Tharchen, T. Performativity as Ongoing Journeys: Implications for Strategy, Entrepreneurship, and Innovation. Long Range Plann. 2018, 51, 500-509. [CrossRef]

31. Palavicini, G.; Cepeda, I. Innovación y Emprendimiento Social en Instituciones de Educación Superior: Students4Change; Tecnológico de Monterrey: Monterrey, Mexico, 2019.

32. Poveda, T.; Alvarez, G.; Vega, V. Libro Generalidades Sobre el Emprendimiento; Editorial Jurídica de Ecuador: Quito, Ecuador, 2019.

33. Taylor, P.; Radharamanan, R.; Juang, J. Innovation and entrepreneurship in engineering education at MUSE. J. Chin. Inst. Eng. 2012, 35, 25-36.

34. Schuelke-Leech, B. Innovation, Industry Engagement, and Entrepreneurship in Engineering Programs Beth-AnneEngagement. In Proceedings of the 2017 Canadian Engineering Education Association, Toronto, ON, Canada, 4-7 June 2017; pp. 14-16.

35. Browder, R.E.; Aldrich, H.E.; Bradley, S.W. The Emergence of the Maker Movement: Implications for Organizational and Entrepreneurship Research. J. Bus. Ventur. 2019, 34, 459-476. [CrossRef]

36. Creed, C.; Suuberg, E.; Crawford, G. Engineering Entrepreneurship: An Example of A Paradigm Shift. J. Eng. Educ. 2002, 91, 185-195. [CrossRef]

37. Luo, X.; Li, H.; Huang, T.; Rose, T. A field experiment of workers' responses to proximity warnings of static safety hazards on construction sites. Saf. Sci. 2016, 84, 216-224. [CrossRef]

38. Mendelson, M. Entrepreneurship in a Graduate Engineering Program. J. Eng. Educ. 2001, 90, 601-607. [CrossRef]

39. Selznick, B.S. Measuring Undergraduates' Innovation Capacities. Res. High. Educ. 2018, 59, 744-764. [CrossRef]

40. Taks, M.; Tynjala, P.; Toding, M.; Kukemelk, H.; Venesaar, U. Engineering Students' Experiences in Studying Entrepreneurship. J. Eng. Educ. 2014, 103, 573-598. [CrossRef]

41. Tao, F.; Qi, Q.; Wang, L.; Nee, A.Y.C. Digital Twins and Cyber-Physical Systems toward Smart Manufacturing and Industry 4.0: Correlation and Comparison. Engineering 2019, 5, 653-661. [CrossRef]

42. Xu, J.; Hou, Q.; Niu, C.; Wang, Y.; Xie, Y. Process optimization of the University-Industry-Research collaborative innovation from the perspective of knowledge management. Cogn. Syst. Res. 2018, 52, 995-1003. [CrossRef]

43. Hebles, M.; Yaniz-álvarez-de-eulate, C.; Jara, M.; Hebles, M.; Jara, M. Impact of cooperative learning on teamwork competence. Coop. Learn. 2019. [CrossRef]

44. Espada, J.S.; López, S.M.; Bel, P.; Lejarriaga, G. Educación y formación en emprendimiento social: Características y creación de valor social sostenible en proyectos de emprendimiento social. Rev. Deestudios Coop. 2018, 129, 16-38.

45. Jiménez-Medina, E.; Rojas-Arenas, I. Competencias Profesionales E Industria 4.0: Análisis Exploratorio Para Ingeniería Industrial y Administrativa para el Área Metropolitana Del Valle De Aburrá. In Encuentro Internacional de Educación en Ingeniería 2019; ACOFI: Cartagena de Indias, Colombia, 2019.

46. Herrera, R.; Vielma, J.C.; Muñoz-La Rivera, F. Impact of microteaching on engineering students' communication skills. Int. J. Eng. Educ. 2018, 34, 1768-1775.

47. Herrera, R.F.; Muñoz, F.C.; Salazar, L.A. Perceptions of the development of teamwork competence in the training of undergraduate engineering students. Glob. J. Eng. Educ. 2017, 19, 30-35.

48. Psacharopoulos, G.; Schlotter, M. Skills for Employability, Economic Growth and Innovation: Monitoring the Relevance of Education and Training Systems, European Expert Network on Economics of Education; EENEE. 2010. Available online: http://www.eenee.de/eeneeHome/EENEE/Analytical-Reports.html (accessed on 12 August 2020).

49. ABET. Criteria for Accrediting Engineering Programs; Engineering Accreditation Commission: Baltimore, MD, USA, 2019.

50. Herrera, R.F.; Muñoz, F.C.; Salazar, L.A. Diagnóstico del trabajo en equipo en estudiantes de ingeniería en Chile. Form. Univ. 2017, 10, 49-61. [CrossRef] 
51. Kember, D.; Ho, A.; Hong, C. Characterising a teaching and learning environment capable of motivating student learning. Learn. Environ. Res. 2010, 13, 43-57. [CrossRef]

52. Stock, T. Perspectives for International Engineering Education: Between used capacity and operational efficiency. Procedia Manuf. 2018, 21, 10-17. [CrossRef]

53. Wiek, A.; Withycombe, L.; Redman, C. Key competencies in sustainability: A reference framework for academic program development. Sustain. Sci. 2011, 6, 203-218. [CrossRef]

54. Passow, H.; Passow, C. What competencies should undergraduate engineering programs emphasize? A systematic review. J. Eng. Educ. 2017, 106, 475-526. [CrossRef]

55. Anderson, L.; Krathwohl, E. A Taxonomy for Learning, Teaching, and Assessing: A Revision of Bloom's Taxonomy of Educational Objectives; Longman: New York, NY, USA, 2001.

56. Solesvik, M. Entrepreneurial competencies and intentions: The role of higher education. J. Forum Sci. Oeconomia 2019, 1, 9-23.

57. Twenge, J.M. iGen; Simon \& Schuester: New York, NY, USA, 2017.

58. Ng, E.S.W.; Schweitzer, L.; Lyons, S.T. New Generation, Great Expectations: A Field Study of the Millennial Generation. J. Bus. Psychol. 2010, 25, 281-292. [CrossRef]

59. Twenge, J.M.; Freeman, E.C.; Campbell, W.K. Generational Differences in Young Adults' Life Goals, Concern for Others, and Civic Orientation, 1966-2009. J. Pers. Soc. Psychol. 2012, 102, 1045-1162. [CrossRef] [PubMed]

60. Kolnhofer-Derecskei, A.; Reicher, R.; Szeghegyi, A. The X and Y Generations' Characteristics Comparison. Acta Polytech. Hung. 2017, 14, 107-125.

61. Črešnar, R.; Nedelko, Z. Understanding Future Leaders: How Are Personal Values of Generations Y and Z Tailored to Leadership in Industry 4.0? Sustainability 2020, 12, 4417. [CrossRef]

62. Peres, P.; Mesquita, A. Gen Z at the workplace: Impact on education and training needs. ICERI2019 Proc. 2019, 383-388. [CrossRef]

63. García, L. The need for digital education in a digital world. Rev. Iberoam. de Educ. Distancia 2019, 22, 9-22.

(C) 2020 by the authors. Licensee MDPI, Basel, Switzerland. This article is an open access article distributed under the terms and conditions of the Creative Commons Attribution (CC BY) license (http://creativecommons.org/licenses/by/4.0/). 